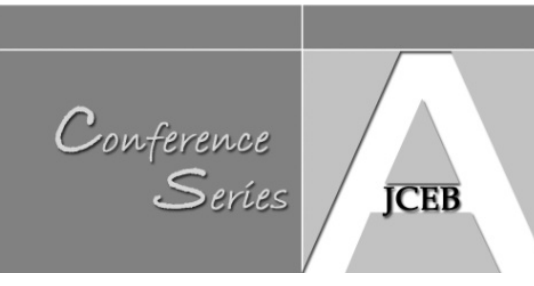

\title{
Innovate or Perish? Exploring some of the Myths of Construction Innovation
}

Martin Loosemore (University of New South Wales, Australia)

\begin{abstract}
The construction innovation literature suggests that managers face a stark choice. They can innovate or perish in the face of growing global competition and an increasingly uncertain and dynamic world. Innovation is presented as a key area of reform needed to raise business performance, yet at the same time it is argued that Australia is falling behind in the global innovation stakes. Evidence suggests that the Australian Construction sector is a poor innovation performer when compared to all-industry averages and contributes relatively little to the national innovation effort. Drawing on international innovation research, this paper argues that these views are overly simplistic and explores some of the myths that surround the process in the construction industry. Through interviews with some of Australia's leading innovators and policy-makers it suggests that many of the factors that are said to drive innovation are not as straight forward as they may seem. There are important qualifications to consider and it would seem that construction innovation is a highly interactive and amorphous process, involving many people with multiple interests dealing with day-to-day challenges.
\end{abstract}

Keywords: Innovation, opportunism, strategy, risk.

\section{Introduction}

Innovation is the process by which organizations successfully transform new ideas into improved products, services or processes, in order to advance, compete and differentiate themselves (Baregheh et al. 2009). Much of the recent interest in innovation has been driven by a growing chorus of economists and business leaders who believe that the world is running out of ideas to deal with the huge challenges which lie ahead. Recent 'Futures' reports like the World Economic Forum's Global Risk Report present managers with a toxic mix of chronic labour market imbalances, rampant climate change, depleting natural resources, unpredictable financial markets and computer and human viruses and digital wildfires which could reap global havoc (WEF 2013). The World Economic Forum's Global Risk Report also shows how these risks are interconnected in ways we don't really understand creating a contagion effect where a small seemingly innocuous event in one part of the global system can cascade through the entire system to affect firms in seemingly remote parts of the system to affect firms in ways in which they find difficult to predict. These challenges must seem insurmountable to most CEOs and government policy-makers. Most are simply trying to survive and consolidate after the global financial crisis and these are not the sorts of problems which can be tackled alone by one individual firm or government. However, as Green et al (2012) point out, this is precisely where innovation comes in. It is the key to survival and competitive advantage in such a uncertain and dynamic business environment. According to Green et al (2012: 5) firms must "innovate or perish" and face a fundamental choice. They can either take the 'low-road' of cost-cutting which is an inevitable 'race to the bottom' and the bottom of the value-chain, or they can take the 'high road' to the top of the value-chain by driving growth through innovation.

However, recent research has revealed a profound concern that Australia is falling behind in the global innovation stakes. For example, the Australian Innovation System Report (DIISRTE 2010) claimed that the construction sector has historically had low levels of 
innovation with only 30.8 per cent of businesses innovating (the lowest of any sector). Daley et al (2012) shows how Australian innovation is focussed in a relatively small number of firms who are 'persistent innovators' in high technology industries such as pharmaceuticals, manufacturing and electronics. Firms in the construction sector do not feature in these lists. While Barlow (2012) has shown a significant increase in private funded R\&D in Australia, this is from a very low base, there is no indication of how effectively this R\&D is implemented and there is a large fudge factor in the way construction firms allocate expenditure to R\&D (design and feasibility study costs often being allowable under government R\&D measurement systems). Also, R\&D statistics are a notoriously inaccurate way of measuring innovation. Other research shows that there is in fact considerable amount of innovation that is 'hidden' from national R\&D statistics (Abbot et al 2007, NESTA 2007, Gambatese and Hallowell 2011). These researchers have shown that in reality innovation in construction is rarely laboratory based, it often happens on the coal-face in response to day to day problems and it is rarely patented. Also, talking about construction innovation is not that simple since when one considers the amorphous nature of the industry. For example, a recent survey of firms in the UK shows that construction manufacturers invest nearly three times as much in R\&D than contractors and twice as much as designers, showing that innovation occurs around the industry rather than within it (Constructionline 2013). However, while the Australian construction sector may well be more innovative than national innovation statistics suggests, few would deny that it can do better. The aim of this paper is to explore how this can be done in conversation with some of Australia's leading construction entrepreneurs and policy makers. It starts by exploring the many recognised institutional, cultural and organizational drivers of innovation which have been highlighted in the construction literature. It then explores their impact in reality and explores some of the myths surrounding these ideas.

\section{Some Accepted Drivers of Innovation in Construction}

Serious attempts to engage with an innovation agenda in the construction industry go back to the 1960s but gathered momentum during the 1980s and 1990s in response to accumulating evidence that the construction industry's performance was unreliable and that it's production processes were unsafe and failing to keep pace with technological advances that were revolutionizing society. While authors such as Winch (2008) have questioned the empirical foundations of such claims and while others such as Ness (2010) and Ness and Green (2012) have argued that many innovations over that time have been counterproductive, there has nevertheless been considerable advancement in our understanding of how innovation works in the industry. While it is impossible here to cover this entire literature, we explore some of the main contributors and drivers below.

\section{Leadership}

Loosemore and Holliday (2012) identify four sources of leadership which are important to innovation in construction:

1) Major clients (private and government) must lead by demanding more innovation and creating a competitive environment where innovation can flourish. Instead of focusing on price alone (which often disadvantages innovative firms), they should recognize the 'value' delivered by innovation over the life cycle of their investment. They should also enable supply chains to have a stake and say in the way it is designed, constructed and performs.

2) Major firms in the construction industry have a responsibility to lead by driving innovation through their supply and demand chains. They can do this by: investing in R\&D; educating clients about the benefits of innovation; being more willing to support

Loosemore, M. 2014, 'Innovate or Perish? Exploring some of the Myths of Construction Innovation', Australasian Journal of Construction Economics and Building Conference Series, 2(2), 44-55 
new ideas; helping smaller business partners to do so; sharing risk and reward and; continuously striving to improve performance on their projects.

3) Innovation is more likely to be driven by the adoption of innovations from outside the industry than from within it. So the leadership of manufacturers and service providers have a critically important role to play in collaborating to drive innovation within the industry.

4) At an industry level there is a need for a champion to catalyze innovation in the same way that Latham did in the 1980s and Egan did in the 1990s in the UK. These people caught the imagination of the industry and engendered a universal appetite for reform never seen in the UK construction industry before.

The important role of the customer has been widely recognized in the construction sector for many years (Wood 1975), Gambatese and Hallowell (2011) Egbu (2008) and Barrett (2008). While Brandon and Shu-Ling (2008) argue that clients shouldn't be relied upon to drive innovation and while Manley (2006) and Sexton et al (2008) argue that that one cannot generalise, other research has shown that many clients may be a barrier to innovation rather than a help. For example, Loosemore and Phua's (2011) research found that many clients are simply unprepared to pay for innovation and are not equipped to assess its value to their business. Sexton et al (2008) found that while some prominent clients take their leadership responsibilities seriously, the majority of construction clients play a passive role in the innovation process. And according to Ivory (2005), many clients are unwilling and unable to effectively encourage innovation because many see buildings as short-term asset and do not understand the relationship between their buildings and their core business performance. This is the economic dilemma of innovation in the construction industry. In reality, the potential for investment in innovation is restricted to the relatively few large companies who are lucky enough to deal with sophisticated clients which procure buildings on a frequent basis. The vast majority of the industry are left to work with clients who procure buildings very rarely, who want the lowest possible price for their investment and who do not see them as a key long-term asset in the success of their core business.

\section{Competition}

The issue of whether competition is good or bad for innovation in the construction sector is a contentious one. Both sides of the argument were put by the Australian Royal Commission into the Building and Construction Industry (RCBCl 2002). The Final Royal Commission report noted that there was virtually no international competition in the Australian construction industry, few alternative products for clients to choose from and significant barriers for new firms wishing to enter the industry. Therefore, it was argued, new players which are likely to be more innovative are excluded from the industry and there is little pressure on existing firms to break rank and run the risk of trying something different. However, while competition is good for innovation, the Australian Royal Commission also noted that excessive competition could also become undermine innovation by forcing down margins to untenable levels. An alternative to head-on competition is to collaborate through competitor and supply chain alliances to share knowledge and the risks of innovation. The importance of collaboration to the innovation process in construction has been highlighted by numerous authors including Leiringer (2006), Walker and Rowlinson (2008) an Walker et al (2013). However, Loosemore et al (2002) found a strong view in the Australian Building and Construction Industry that competition means working 'against', rather than 'with' ones' competitors and Tennant and Fernie's (2013) research found that, while over the last decade principles of supply chain collaboration have been promoted extensively within the construction sector, collaborations are rare and shallow and the aim of fully integrated supply chains an aspiration rather than a reality.

As Loosemore and Holliday (2012) argue, the basis of the collaboration argument is that few firms in the construction industry have the full range of competencies necessary to innovate.

Loosemore, M. 2014, 'Innovate or Perish? Exploring some of the Myths of Construction Innovation', Australasian Journal of Construction Economics and Building Conference Series, 2(2), 44-55 
So they must collaborate to do so. Collaboration not only creates the broad knowledge and skills-base to generate and convert new ideas into reality but also spreads the significant risk associated with innovation. To drive innovation, collaborative arrangements must extend beyond the traditional boundaries of the construction industry. The solutions to the major challenges the industry faces will also causes us to question the efficacy of vertically hierarchical and integrated business models in favour of horizontally dispersed network models with permeable boundaries. This will require construction business, communities and governments to work in new organizational configurations which are likely to challenge traditional competitive relationships and perceptions. Loosemore and Holliday (2012) argue that notions of interdisciplinarity and collaboration will replace traditional competition as a way to share complementary ideas, resources and capabilities to mutual advantage. Procurement reform will also be critical to this process. New approaches will need to enable 'deeply integrated' supply chains where suppliers, manufacturers, designers, contractors, sub-contractors, operators and clients work collectively to share the risks and rewards associated with innovation in an open, transparent and collaborate environment of collective responsibility where personal interests are put aside in the interests of the whole and where resources are shared and used where they best fit.

\section{Projects}

As Loosemore and Phua (2011) point out, in construction "the project is king" and numerous authors have argued that the project-based nature of construction inhibits the spread of innovations from one project to the next, ensuring that any diffusion remains limited to isolated pockets (Winch 1998, Widen 2006). However, Barrett and Lee's (2004) research into the perceived barriers to innovation in the construction sector ranked it last out of fourteen factors and Dodgson et al (2005) argue that project-based organizations can be highly conducive to innovation because they exhibit similar properties to Burn's and Stalker's (1961) organic form of organization, offering the flexibility for people to experiment with new ideas and avoiding the rigidity of more routine type work and environments. The problem, according to Dodgson et al (2005) is not projects themselves but the challenge in realizing these benefits by establishing a way for independent project-based organizations to exist alongside more traditional divisional or functional structures in a way which allows the benefits of innovation to be learnt and transferred from project to project.

\section{Fragmentation}

Building production takes place through a fragmented supply and demand chain which physically and chronologically separates customers from designers, designers from builders and builders from operators. On most projects, these chains are also 'legally fragmented' by the way risks and rewards are distributed rather than being shared between project participants. According to Winch (2008) each firm in the construction supply chain compete to extract the greatest share of the value-stream flowing from the client. In theory this should be shared in proportion to their contribution to that value-stream process. However, Akintoye et al 2003, Jefferies and Mcgeorge 2008 and Smith et al (2006) found, power differences between the parties ensures that in most projects value may not be extracted proportionately on this basis and this often results in confrontational relationships and a lack of collective responsibility for project success. Lamborde and Sanvido (1994) and Gann (2000) argue that this is one of the construction industry's major barriers to innovation - the separation of potential innovators from the potential benefits of their innovations. The result is that innovators further down the supply chain are more often than not, separated from the final market into which their new idea is incorporated.

\section{Governance and regulation}

As Fairclough (2002) pointed out, governments play a central role in the innovation process as a regulator, sponsor, client and policy maker. However, with worldwide trends towards 
privatization of public assets and an associated loss of skills and knowledge to lead the industry to innovate, the public sector's role in driving innovation has retreated to being largely regulatory and policy directed. While many argue that regulation has a very small role to play in innovation since it cannot address deeply ingrained cultural problems in the industry, Loosemore and Holliday (2012) argue that regulation is important in driving change because much of the construction industry will not innovate voluntarily. Construction is a compliance-based sector with a long-tail of low performing firms which must be encouraged to change through regulation and legislation which mandates minimum standards and creates incentives to innovate. The industry also needs standard methods and metrics for measuring and demonstrating the benefits of innovation. These targets need to be incrementally improved over time to drive-up performance. However, the need for regulation must be balanced with the dangers of over-regulation which when badly designed is also known to stifle innovation through increasing red tape and compliance costs which can slow down the innovation process and make it economically unviable. In Australia for example, there are over seventy overlapping bodies within the industry with different and often conflicting interests and agendas. As the Cole Royal Commission into the Building and Construction Industry noted, these are unlikely to come together and agree on an agenda to bring about meaningful change within the industry (RCBCl 2002).

Another institution which plays an important role in industry reform is the union movement. While disempowered in many countries over the last twenty years, few would argue that unions have played and continue to play a critically important role in driving innovation through their scrutiny of management practices, particularly in areas such as occupational health safety and welfare. However, the role of unions in the innovation process has been contentious and opinions are polarized as to whether they are a positive or negative force for innovation. For example, some argue that the relatively difficult and often, openly aggressive employer/union relations in the Australian Building and Construction Industry have been a major impediment to reform by institutionalizing restrictive trade practices and forcing up wages without commensurate increases in productivity (Garling 1991, RCBCl 2002). Conversely, others argue that Union activities have had a positive impact on industry reform over the years by driving change and industry improvement in areas that affect workers' rights, conditions and health and safety. As MacLeod and Clarke's (2010) report to the UK government showed, unions represent an important independent voice' for workers and play a significant role in strengthening employee engagement which is directly correlated to levels of company innovation.

\section{Attitudes}

Toole (1998) argue that positive attitudes towards innovation are the most fundamental building block of reform. Yet, in a study of innovation in the construction sector, Lenard (1996) and Loosemore et al (2002) found that innovation is widely perceived as an academic activity, which in most instances, produces theoretical results of little commercial value. There are clearly many reasons for culture but research indicates that it has its roots in ten main construction industry characteristics (Loosemore et al 2003; Dainty and Loosemore 2012):

1. The increasingly theoretical research which is undertaken at "research-intensive" universities (this is discussed in more detail in chapter five);

2. The inability of many academics to communicate the value of their results to industry;

3. The masculine culture of the construction industry;

4. The lack of diversity in the industry and the under-representation of minority groups;

5. The tradition of physical activities which cannot be learnt in a classroom environment;

6. The high pressure project environment which provides little time to reflect on the potential value of new knowledge;

7. The underlying commercial values of the industry which produce a short-term and narrow focus on financial returns; 
8. The vertical fragmentation of the industry into a multitude of SMEs which do not the foresight, inclination or funds to invest in R\&D, training and education;

9. The horizontal fragmentation of the supply chain into separate design, construction and operational activities which prevents the integration of knowledge and collective responsibility needed to innovate;

10. The tradition of passing risks to the lowest common denominator in supply chains and starving them of resources to invest in innovation.

\section{People}

Gann $(2000,2003)$ argued that more construction innovation will require both a deep and a broad gene pool which provides the expertise and diversity which is the basis of innovation. However, as Dainty and Loosemore (2012) point out in their critical review of human resource practices in the industry, attracting the best people (deepening the gene pool) is not an easy task given the increasing competition from other industries for human resources. This will depend on improving the industry's image and reputation by improving working conditions and performance and by highlighting the important and positive contribution it makes to the economy, culture, environment and to wider society. Broadening the gene pool will require the industry to address the under-representation of minority groups all levels. For example, women are seriously underrepresented at senior levels in the industry, minority groups such as migrants are often poorly treated and there are few education and career pathways for trade operatives to work their way up into management roles. To alleviate this problem, equity and diversity initiatives need to be taken seriously and education needs to be more flexible to in enabling people to learn at work, to recognize prior and experiential learning on-the-job and to offer clearer pathways and transitions between all levels of education in the industry. It is also important to ensure that education is relevant to what industry needs and that it contributes to the performance of firms in the industry, while at the same time providing the broad-based liberal education needed to think differently. Finally, there needs to be stronger ties between universities, governments and commerce to ensure the industry can independently monitor the benefits of innovation and learn lessons to improve future processes.

\section{Method}

The above discussion is by no means exhaustive but suggests that construction innovation could be increased by:

- Stronger thought leadership from clients and major firms in the industry.

- Closer relationships between innovators, clients and end-users.

- More integrated supply chains.

- Reduced emphasis upon price and increased the focus on value.

- Developing metrics to measure innovation and methods to value innovation.

- Collaborative procurement systems which emphasize negotiation not competition.

- More equitable sharing of risk and opportunity associated with innovation.

- More realistic resourcing of projects.

- A willingness to work with competitors and the supply chain for mutual benefit.

- Improved communication between research, production and marketing functions.

- Imaginative and effective training to develop peoples' innovative capabilities.

- A more diverse workforce with clearer pathways for under-represented groups.

To explore the realities of implementing these ideas in practice, semi structured interviews were conducted with thirty two senior business leaders and government policy makers who have been influential in driving innovation in the construction sector. The sample was made up of senior executives from across the entire construction demand and supply chain (Table 1). 
Table 1: Sample structure

\begin{tabular}{|l|l|}
\hline Role & Number \\
\hline Government & 5 \\
\hline Clients & 3 \\
\hline Consultants & 5 \\
\hline Developers & 5 \\
\hline Contractors & 6 \\
\hline Subcontractors & 4 \\
\hline Manufacturers & 4 \\
\hline TOTAL & 32 \\
\hline
\end{tabular}

The interviews encouraged respondents to tell their stories of innovation success and failure and in presenting the results of the interviews the narrative of the stories are provided to retain the full richness of insight contained in the narratives collected.

\section{Discussion of Results}

In general, there was consensus that innovation won't happen unless the leadership is there to realize that vision by enacting the strategy..... "People need to see the organization does new things - visibility is critical....you can't tell people...you need to show them". Most respondents thought that the job of the leader is to clearly articulate the reason for innovating... "having a project to win, a problem to solve and a cause which people can rally around is important... Having a focus and a reason to innovate provides the thirst for knowledge that drives innovation... "it opens your eyes and encourages you to go looking for new ideas". Strong, focused and determined leadership is critical in overcoming many of the inevitable barriers which will confront innovators in the construction industry. Without leadership "innovation doesn't get an agenda or quantum" and "is directionless".

As well as providing focus, most thought that the role of the leader was to build an innovation culture... "they set the tone in a company and the risks associated with failure". An innovation culture was seen as critical by everyone. This should not only define a particular way of thinking but it should also ensure that there is a level of maturity and continuity to the process.

Clients were seen to have a particularly important leadership role and to be essential in creating a market for innovation ... "Clients play a critical role in the innovation process since they pay for it" and innovative firms strive to "attract themselves to clients that value innovation". However, it was widely felt that most construction clients are not open to innovation or prepared to pay for it... "most clients are completely irrelevant to innovation. They have no interest in it what so ever. Unless of course it can reduce costs .. then they have a great desire for innovation". There was a sense that many do not have the tools to value innovation and prefer to minimize short-term capital costs, go to tender and maximize predictability of outcome by transferring risks to the construction industry. As a number of respondents complained, "by the time we are involved in a project it's too late... the solution is locked in and the value-adding opportunities are reduced to a trickle"...

Having emphasized the role of the market in driving innovation, good government innovation policy was also widely seen as critical to "stimulating the conversation" and "setting the enabling environment in which innovation can occur"... "where firms can profit from innovation" and markets can operate effectively. Governments were seen to play a critical role in providing innovation infrastructure, capital (financial, physical and social) and regulation to encourage change and to protect innovators from "the race to the bottom". The government can also set minimum standards through certification systems and codes of practice... "although they can also ossify and inhibit innovation by constraining thinking if 
badly designed and managed". To avoid this, certification systems must not be prescriptive but must be performance-based and give people space to innovate in achieving those performance standards. However, ultimately all respondents thought that innovation should be market led if it is to be sustainable. If the government introduces greater tax concessions for R\&D then firms will tend to respond, but the impact is relatively small. For example, as one respondent pointed out, "Many firms simply see R\&D tax concessions as another opportunity for creative accounting which allows them to squeeze more money out of their operations rather than to innovate".

While the concept of integration was widely considered as critical for innovation, many agreed that the ideal of integration is often unachievable in practice and that it is important not to lose sight of the need for business accountability. As one of the respondents said, "One of the big mistakes people make it pursuing integration is to assume that one has to abandon accountability in the pursuit of trusting and open relationships. There is a mistaken assumption that being 'business-like' destroys trust whereas in reality the opposite is true. While integrated teams are important to drive innovation, if done without regard for proper accountability then it can often be a "bridge too far" for clients". One of the reasons for this is that many directors on the boards of clients are lawyers, which creates a powerful reluctance at governance level to move away systems which appear, at least in the short-term, to offer some form of accountability and control over costs. It is critical that in pursuing innovation and interpreting much of the literature in this area, ideas from other sectors must often be tempered by the reality of the construction industry. The imposition of a completely loose system onto an industry that is "fundamentally dysfunctional" could potentially create more problems that it would solve.

There was also agreement that innovation revolves around people. As one respondent stated,... "at the start there needs to be a predisposition to innovation.. then there is a need to hand over to people to make them a reality".... "there is a need for people who can think outside the square and people who think inside the square". While an innovation strategy must have a structure and focus, most felt that it was also important to ensure that it is broad enough to allow people to move within it. Innovative firms tend to have a loose and mobile business strategy which is built around their people's capabilities, desires and passions. As their people develop so does their strategy and this enables firms to reinvent themselves and gravitate to where the work is in an ever changing construction market. In most instances, this is not a structured process. As one respondent said, "It just happens". This means that, it is not uncommon for new business units to emerge out of the personal interests and passions of individuals... "you find out what people are interested in and help them explore those ideas".

The forgotten layer of people in the industry who some felt were largely ignored in the innovation process were the construction workers who undertake the work on site. It was felt that the drive for greater flexibility in the industry over many years has resulted in them being forced into casualized labour, reducing their ability to participate in workplace issues. ......"The structure of employment in the construction industry is all about lowering costs and providing flexibility rather than being about innovation. Contrast this with the manufacturing sector where in a factory of one hundred workers there are all sorts of opportunities for them to contribute ideas and to talk to managers"... "it's a race to the bottom". Many respondents pointed out that one of the major negative consequences of this employment structure is that the subcontractors who are expected by the large builders to innovate are largely separated from the benefits of doing so by repeated subcontracting and by a widespread "risk transfer mentality" which ensures that those who need to innovate are rarely able to benefit from them. Many also pointed to the by a lack of investment training in the industry which has resulted in a stagnation of ideas. Firms who provide apprenticeships and develop their staff are in the minority and can place themselves at a major cost disadvantage to those which do not. This has had a huge impact on innovation by effectively 
freezing the intellectual development of the industry. As one respondent said.. "The basic skills levels of workers in other industries are far higher generally than they are in construction. The knowledge base of workers in construction has hardly developed in the last twenty years because of the subcontracting revolution".

Collaboration was also seen as essential to successful innovation.... "its very rare for successful innovators to work in a vacuum"... "collaboration is critical to get ideas across the line. The more people you can take the better". However, when talking about collaboration, there was also some cynicism. "Collaboration is just a word... there is nothing new in this.. what it really means is that innovation comes from activity... activity spurs mutation.. if there are more people working together on something then there is a greater chance of new ideas happening". In construction, competition was widely seen as a barrier to collaboration ..... "you can lose that competitive edge if you involve subcontractors too early. It can cause you to lose the job". Competition is not only a problem for subcontractors. It is also a problem at a higher level...... "collaboration in construction is a huge challenge. There is always a sense that one is giving away something. The industry is so competitive that collaboration between the few big firms is almost impossible".

For true collaboration to happen in construction, most argued that it was important to be involved early in the design process where solutions can be jointly developed. Most of the respondents talked about "going on a journey" .... "early on the door is fully open to innovation.. but this is a highly protected place to be and most people are faced with a firmly closed door". Another issue raised by respondents was the lack of depth in the subcontracting sector which makes collaboration difficult to implement in practice. The subcontracting market is dominated by a relatively few large firms and there is a long tail of tier-two and tier-three firms which have very low management capability. Collaboration can therefore become highly incestuous as competitors draw on the same pool of subcontractors to do their work. Innovation in this environment comes out of the 'quality' of the relationship formed with a subcontractor. However, this is also problematic because no subcontractor is able to commercially survive if they tied themselves into a special relationship with one contractor. On the other hand, no contractor wants to get too close to a subcontractor because they lose the element of competition which might make the difference between losing or winning a project. As one respondent pointed out, "so there is a stand-off. Everyone wants to collaborate in the ideal world but no-one can because it involves giving away your competitive advantage".

Another common problem is that collaboration with subcontractors often has to occur through union intermediaries and there are plenty of tensions here which can obstruct the innovation process. Views about the role of unions in the innovation process were typically polarized. Some firms have a confrontational approach to unions and see them as a barrier to innovation while others believe that it is easier to work with unions.

\section{Conclusion}

The aim of this paper was to introduce some basic principles of innovation and explore some of the myths that surround the process in the construction industry. It is evident that innovation is a complex and multidimensional process which doesn't always occur in the way the literature says it does. The innovation process is far from predictable but is messy, uncontrollable, unpredictable and difficult to define. Innovation in construction more-oftenthan not, appears to happen in unplanned ways in response to day-to-day problems. The beginning and end of the innovation process is hard to determine and it is highly interactive and cyclical, involving many people with multiple interests creating new knowledge under the influence of market and many other social, political and organizational forces. While the sector is often derided for being 'low innovation' the reality is that it is a highly creative industry that is adept at solving complex operational problems on a project-by-project basis.

Loosemore, M. 2014, 'Innovate or Perish? Exploring some of the Myths of Construction Innovation', Australasian Journal of Construction Economics and Building Conference Series, 2(2), 44-55 
Many of these creative activities are not detected by traditional measures of R\&D and the challenge that faces the industry is how to appropriate the benefits of this creativity across projects and throughout the supply chain. However, it is clear that the adoption of many of the above recommendations will require a fundamental mind-set shift within the construction industry. While there are clearly many institutional, organizational and cultural barriers which can prevent this from happening, the upside is that those that address them have the potential to reap extraordinary rewards among competitors who remain unsophisticated and slow to adapt to an increasingly uncertain and dynamic business environment which is full of new opportunities. The challenge of innovation is to recognize and harness this.

\section{References}

Abbott, C., Barrett, P., Ruddock, L \& Sexton, M. 2007, 'Hidden innovation in the construction and property sectors', RICS Research paper series, Volume 7 Number 20 December.

Akintoye, A. Beck, M \& Hardcastle, C. 2003, Public-Private Partnerships: Managing Risks and Opportunities, Blackwell, Oxford, UK.

Barlow, T. 2012, The Built Environment Sector in Australia. R\&D Investment Study: 1992-2010. Sustainable Built Environment National Research Centre, Brisbane.

Baregheh, A., Rowley, J \& Sambrook, S. 2009, 'Towards a multidisciplinary definition of innovation', Management Decision, 47(8), 1323-39

Barrett, P. 2008, 'A Global Agenda for Revaluing Construction: The Client's Role', In Brandon, P \& Shu-Ling, L (eds), Clients Driving Innovation, Wiley- Blackwell, Oxford, UK.

Barrett, P. S \& Lee, A. 2004, Revaluing construction: International survey questionnaire results, CIB, The Netherlands.

Barrett, P. Sexton, M \& Lee, A. 2008, Innovation in small construction firms, Spon Press, London.

Brandon P \& Shu-ling, L. 2008, Clients driving innovation, Wiley-Blackwell, Oxford,UK.

Burns, T \& Stalker, G. M. 1961, The management of innovation, Tavistock, London.

Constructionline 2013, Constructionline News 17 April 2013, Constructionline and Capita Symonds survey finds some construction companies slow to innovate, http://www.constructionline.co.uk/static/news/2013/innovationsurvey.html, accessed November $15^{\text {th }}$ 2013,: 2.00pm.

Dainty, A \& Loosemore, M. 2012. Human resource management in construction: critical perspectives, Routledge, London.

Daley, J. 2012, Game-changers: Economic reform priorities for Australia. Grattan Institute, Sydney, Australia.

D.I.I.S.R. 2010, Australian Innovation System Report 2010, Industry Innovation Councils team Manufacturing Division, Department of innovation, industry, science and research, Commonwealth government of Australia, Canberra.

Dodgson, M., Gann, D \& Salter, A. 2005, Think, play, do - technology, innovation, and organization, Oxford University Press, Oxford.

Egbu, C. 2008, 'Clients' roles and contributions to innovations in the construction industry: when giants learn to dance', In Brandon P \& Shu-ling L (eds), Clients driving innovation, Wiley-Blackwell, Oxford, 69-77.

Fairclough, J. S. 2002, Rethinking construction innovation and research; a review of government policies and practices, Department of Trade and Industry, London, UK.

Gambatese, J. A \& Hallowell, M. 2011, 'Factors that influence the development and diffusion of technical innovations in the construction industry', Construction Management and Economics, 29 (4), 507-17.

Loosemore, M. 2014, 'Innovate or Perish? Exploring some of the Myths of Construction Innovation', Australasian Journal of Construction Economics and Building Conference Series, 2(2), 44-55 
Gann, D. M. 2003, 'Guest editorial: innovation in the built environment', Construction Management and Economics, 21 (4), 553-5.

Gann, D. M. 2000, Building Innovation - complex constructs in a changing world, Thomas Telford, London.

Garling, P. 1991, Research and development - preparing for the next building boom: The project deliverer's view, Building Science Forum of Australia, Sydney, Australia.

Green, R., Toner, P \& Agarwal, R. 2012, Understanding productivity - Australia's choice, University of Technology, Sydney.

Ivory, C. 2005, 'The cult of customer responsiveness: is design innovation the price of a clientfocused construction industry?', Construction Management and Economics, 23(8), 861-70.

Jefferies, M \& McGeorge, D. 2008, 'Public-private partnerships: a critical review of risk management in Australian social infrastructure projects', Journal of Construction Procurement , 14(1), 66-80.

Lamborde, M \& Sanvido, V. 1994, 'Introducing new technologies into construction companies', ASCE Journal of Construction Engineering and Management, 120(3), 334-45.

Leiringer, R. 2006, 'Technological innovations in PPPs: incentives, opportunities and actions', Construction Management and Economics, 24 (3), 301-8.

Lenard, D.J. 1996, Innovation and industrial culture in the Australian construction industry: A comparative benchmarking analysis of critical cultural indices underpinning innovation, Unpublished PhD Thesis, University of Newcastle, Newcastle, Australia.

Loosemore M, Choo H \& Koh J. 2002, 'Encouraging R\&D in construction', ASCE Journal of Professional Issues in Engineering Education and Practice, 128(1), 25-30.

Loosemore, M \& Phua, F. 2011, Corporate social responsibility in the construction industry: doing the right thing? Routledge, London, UK.

Loosemore, M Dainty, A \& Lingard H. 2003, Human resource management in construction projects: strategic and operational approaches, Taylor and Francis, London, UK.

Loosemore, M \& Holliday, S. 2012, 'Pro-innovation bias in construction', Association of Researchers in Construction Management (ARCOM): $28^{\text {th }}$ Annual Conference, Edinburgh, United Kingdom. 3-5 Sept. 2012, 787-97.

MacLeod, D \& Clarke, N. 2010, Engaging for success, Office of Public Sector Information, UK Government, London, UK.

Manley, K. (2006) The innovation competence of repeat public sector clients in the Australian construction industry, Construction Management and Economics, 24 (2) 1295-1304.

Nam, C. N \& Tatum, C. B. 1992, 'Strategies for technology push - Lessons from construction innovations', ASCE Journal of Construction Engineering and Management, 18(3), 213-34.

Nam, C. N \& Tatum, C. B. 1997, 'Leaders and champions for construction innovation', Construction Management and Economics, 15(3), 259-70.

Ness, K \& Green, S. 2012, 'Human resource management in the construction context: if only we could find those workers', In Dainty, A \& Loosemore, M (eds) HRM in Construction: Critical Perspectives, Routledge, London.

Ness, K. 2010, The discourse of 'Respect for People' in UK construction, Construction Management and Economics, 28(5), 481-93.

N.E.S.T.A. 2007, Hidden Innovation: how innovation happens in six 'low innovation' sectors, National Endowment for Science, Technology and the Arts, London, UK.

R.C.B.C.I. 2002, Final Report, Royal Commission into the Building and Construction Industry, Melbourne, Australia.

Sexton, M., Abbot, C \& Shu Ling, L. 2008, Challenging the illusion of the all powerful clients role in driving innovation, in Brandon \& Shu-Ling (eds.) Clients driving innovation, Wiley- Blackwell, Oxford,43-49. 
Smith N J, Merna, T \& Jobling, P. 2006, Managing risk in construction projects, Blackwell publishing, Oxford, UK.

Tennant, S \& Fernie, S. 2013, 'Organizational learning in construction supply chains', Engineering, Construction and Architectural Management, 20(1), 83-98.

Toole, M. 1998, 'Uncertainty and home builders' adoption of technological innovations', ASCE Journal of Construction Engineering and Management, 124(4), 323-32.

Walker, D. H. T \& Rowlinson, S. 2008, Procurement systems: a project management perspective, Taylor and Francis, London, UK.

Walker D, Harley J \& Mills A. 2013, Longitudinal study of performance in large Australiasian Public sector infrastructure alliances 2008-2013, Centre for Integrated Project Solutions, RMIT University, Melbourne, Australia

Widen, K. 2006, Innovation diffusion in the construction sector, Doctoral dissertation, October 2006, University of Lund, Sweden.

Winch, G. 1998, 'Zephyrs of creative destruction: understanding the management of innovation in construction', Building Research and Information, 26(4), 268-79.

Winch G M. 2008, 'Revaluing construction: implications for the construction process', in Brandon P \& Shu-ling L (eds.), Clients driving innovation, Wiley-Blackwell, Oxford, 16-25.

Wood, S. K. 1975, The Public Client and the Construction Industries, HMSO, London. 